Research article

\title{
The memory of iron stress in strawberry plants
}

\author{
Florinda Gama a, *, Teresa Saavedra a, José Paulo da Silva ${ }^{a}$, Maria Graça Miguel a, \\ Amarilis de Varennes ${ }^{b}$, Pedro José Correia ${ }^{a}$, Maribela Pestana ${ }^{a}$ \\ ${ }^{a}$ MeditBio - Center for Mediterranean Bioresources and Food, University of Algarve, FCT, Ed8, Campus of Gambelas, 8005-139, Faro, Portugal \\ ${ }^{\mathrm{b}}$ LEAF - Linking Landscape, Environment, Agriculture and Food, Instituto Superior de Agronomia, University of Lisbon, Tapada da Ajuda, 1349-017, Lisbon, \\ Portugal
}

\section{A R T I C L E I N F O}

\section{Article history:}

Received 28 January 2016

Received in revised form

11 March 2016

Accepted 12 March 2016

Available online 15 March 2016

\section{Keywords:}

Fragaria ananassa

Iron deficiency

Nutrients

Organic acids

Recovery

\begin{abstract}
A B S T R A C T
To provide information towards optimization of strategies to treat Fe deficiency, experiments were conducted to study the responses of Fe-deficient plants to the resupply of Fe. Strawberry (Fragaria $\times$ ananassa Duch.) was used as model plant. Bare-root transplants of strawberry (cv. 'Diamante') were grown for 42 days in Hoagland's nutrient solutions without $\mathrm{Fe}(\mathrm{Fe} 0)$ and containing $10 \mu \mathrm{M}$ of $\mathrm{Fe}$ as Fe-EDDHA (control, Fe10). For plants under $\mathrm{Fe} 0$ the total chlorophyll concentration of young leaves decreased progressively on time, showing the typical symptoms of iron chlorosis. After 35 days the Fe concentration was $6 \%$ of that observed for plants growing under Fe10. Half of plants growing under Fe0 were then Fe-resupplied by adding $10 \mu \mathrm{M}$ of Fe to the Fe0 nutrient solution (FeR). Full Chlorophyll recovery of young leaves took place within 12 days. Root ferric chelate-reductase activity (FCR) and succinic and citric acid concentrations increased in FeR plants. Fe partition revealed that FeR plants expressively accumulated this nutrient in the crown and flowers. This observation can be due to a passive deactivation mechanism of the FCR activity, associated with continuous synthesis of succinic and citric acids at root level, and consequent greater uptake of $\mathrm{Fe}$.
\end{abstract}

๑ 2016 Elsevier Masson SAS. All rights reserved.

\section{Introduction}

Plants are an important source of iron (Fe) in human diet. Although $\mathrm{Fe}$ is quite abundant in soils, the incidence of Fe deficiency is common in plants grown in calcareous soils due to reduced bioavailability of the metal (Hindt and Guerinot, 2012). The low mobility of Fe in calcareous soils reduces the photosynthetic rate and alters chloroplast structure, leading to symptoms in young leaves generally described as chlorosis. Under these conditions plants show limited growth and yields, and the quality of fruit is poor (Domenico Rombolà et al., 2003; Larbi et al., 2006; Pestana et al., 2003) Under Fe deficiency, sensitive crops often present a nutrient imbalance of $\mathrm{Fe}, \mathrm{P}, \mathrm{Mn}$ and $\mathrm{Zn}$ resulting in low availability of such nutrients for metabolic needs (López-Millán et al., 2001a;

Abbreviations: BPDS, Fe(II)-bathophenantrolinedisulfonate; Chl, Chlorophyll; DW, dry weight; EC, electrical conductivity; EDDHA, ethylenediamine-N-N'bis $(0-$ hydroxyphenylacetic) acid; EDTA, ethylenediamine-tetraacetic acid; FCR, ferric chelate reductase; FW, fresh weight; MES, 2-(N-morpholino)ethanesulfonic acid; SPAD, soil and plant analyser development.

* Corresponding author.

E-mail address: fmgama@ualg.pt (F. Gama).
Ortas et al., 2015; Venturas et al., 2014).

Iron acquisition and transport by plants follow two general strategies (Marschner et al., 1986; Muneer et al., 2014). Strategy I, also known as the reduction strategy, occurs in non-grass species which require a reduction of $\mathrm{Fe}(\mathrm{III})$ to $\mathrm{Fe}(\mathrm{II})$ before uptake through a membrane bound ferric-chelate reductase (FCR, belonging to the FRO/Ferric Reduction Oxidase family genes). Fe(II) is then transported to the symplast by Iron Regulated Transporters (IRTs), which belong to the ZIP family (ZIP: zinc and iron protein; a metal transporter family which are able to transport a selection of cations, such as cadmium, iron, manganese and zinc) and show affinity to other transition metals. Plants following this strategy also release organic acids through their roots, resulting in an acidification of the rhizosphere, accentuated by the $\mathrm{H}^{+}$excretion. Organic acids also play an important role in Fe bioavailability in the rhizosphere and in Fe translocation within the plant (Abadía et al., 2002; López-Millán et al., 2001a). Citric acid transports Fe(III) in the xylem sap and usually shows higher concentrations in the xylem and roots of Fechlorotic plants. Concentration increases of citric acid as well as in malic have been related with Fe uptake into various plant organs (Gayomba et al., 2015; López-Millán et al., 2000; Rellán-Álvarez et al., 2010; Zocchi et al., 2007). A second Strategy II, also referred 
as the chelation strategy, is confined to gramineous plants. Grasses release Fe chelator compounds, for example phytosiderophores from the mugineic acid (MAs) family, to solubilize Fe in the rhizosphere prior to uptake (Jeong and Guerinot, 2009).

To sustain metal homoeostasis, plants developed signalling mechanisms that control internal and external metal concentrations, and evaluate interactions between different nutrients (Rubio et al., 2009). These regulation mechanisms determine a balanced nutritional status and lead to a continuous management of uptake, utilization and storage of metals in plants.

The dynamics of nutrient partition in plants under Fe-deficiency have been documented in several crops. For example, in chlorotic citrus rootstocks, macronutrients and micronutrients decreased in the shoots (Pestana et al., 2005). In rice, changes in the partition of nutrients in response to Fe stress depend on the organ: macronutrients accumulate in leaves ( $\mathrm{Ca}, \mathrm{Mg}$ and $\mathrm{K}$ ) while micronutrients accumulate in roots $(\mathrm{Zn}, \mathrm{Mn}$ and $\mathrm{Cu})$. Fe deficiency can lead to decreases of $\mathrm{Ca}, \mathrm{Mn}$ and $\mathrm{Fe}$ in roots, and of $\mathrm{Zn}$ and $\mathrm{Ni}$ in leaves (Sperotto et al., 2012). Another study conducted in kiwi showed increases in leaf $\mathrm{N}$ and $\mathrm{P}$ and a decrease in $\mathrm{Fe}$ concentration (Domenico Rombolà et al., 2003).

Strawberries are popular worldwide due to their antioxidant capacity and richness in essential nutrients (Giampieri et al., 2014, 2015; Manganaris et al., 2014). However, in strawberry (Fragaria $\times$ ananassa Duch.) the knowledge about the effects of $\mathrm{Fe}$ homoeostasis is scarce. As described for other crops, Fe deficiency induces higher activity of the FCR enzyme as part of the standard reduction strategy (López-Millán et al., 2001b). It was reported by Pestana et al. (2012b) that the deactivation of the root FCR enzyme in chlorotic strawberry plants (cv. 'Selva') was slower if a pulse of $\mathrm{Fe}$, in this case as ferrous sulphate, was added to the root system compared to foliar application. It was concluded that this "delay" was an opportunity for plants to take up greater amounts of Fe from the solution.

Under Fe deficiency a complex set of mechanism is activated and we expect that during this window of time an opportunity is created to potentiate Fe uptake and translocation. Moreover, we expect that this translocation will be directed towards selective and physiological important sinks. The aim of this work is to decipher the responses of Fe deficient strawberry plants upon Fe resupply, relating the profile of organic acids and the concentration of nutrients in different organs.

\section{Material and methods}

\subsection{Plant material and growth conditions}

Strawberry bare-root plants, obtained from a nursery, were grown in a glasshouse under natural photoperiod conditions and air temperature $\leq 25^{\circ} \mathrm{C}$. Plants were disinfected by soaking them in a $2 \mathrm{~g} \mathrm{l}^{-1}$ fosetyl-aluminium solution for $2 \mathrm{~h}$. They were then transferred to 20-1 plastic containers filled with a complete and full-strength Hoagland solution with (in $\mathrm{mM}$ ): $5 \mathrm{Ca}\left(\mathrm{NO}_{3}\right)_{2}, 5 \mathrm{KNO}_{3}$, $1 \mathrm{KH}_{2} \mathrm{PO}_{4}, 2 \mathrm{MgSO}_{4}$ and (in $\mu \mathrm{M}$ ): $46 \mathrm{H}_{3} \mathrm{BO}_{3}, 0.8 \mathrm{ZnSO}_{4}, 0.4 \mathrm{CuSO}_{4}, 9$ $\mathrm{MnCl}_{2}$, and $0.02 \mathrm{MoO}_{3}$. Iron was supplied as $\mathrm{Fe}(\mathrm{III})$-EDDHA (Basafer ${ }^{\circledR}$ from Compo, with $6 \%$ of Fe; $5.0 \%$ of Fe chelated by ortho-ortho EDDHA) at two concentrations: 0 (Fe0; $\mathrm{n}=119$ plants) or $10 \mu \mathrm{M}$ of Fe (Fe10; $\mathrm{n}=77$ plants). Plants in Fe10 (positive control plants) were grown with an adequate Fe level. Fe0 plants were used as a negative control. The initial $\mathrm{pH}$ of nutrient solutions was adjusted to $6.0 \pm 0.1$ using a $\mathrm{NaOH} 0.1 \mathrm{M}$ aqueous solution and their electrical conductivity (EC) was $2.2 \pm 0.1 \mathrm{dS} \mathrm{m}^{-1}$ in all cases. The $\mathrm{pH}$ and EC of solutions were monitored daily. When the EC value reached $2.0 \pm 0.1 \mathrm{dS} \mathrm{m}^{-1}$ the solutions were renewed.

As expected, control plants grown with $\mathrm{Fe}(\mathrm{Fe} 10)$ in the nutrient solution did not develop symptoms throughout the entire experiment and Chlorophyll values were always above $720 \mu \mathrm{mol} \mathrm{m} \mathrm{m}^{-2}$. After 35 days plants under Fe0 conditions developed chlorotic strawberry leaves showing SPAD values between 0 and 21 $\left(\mathrm{Chl}<376 \mu \mathrm{mol} \mathrm{m} \mathrm{m}^{-2}\right.$ ). At this stage, the chlorotic plants were divided into two groups: (i) one set remained without $\mathrm{Fe}(\mathrm{Fe} 0)$, and (ii) for the other set (FeR) the nutrient solution was supplemented with $10 \mu \mathrm{M}$ of Fe in order to evaluate the effects of recovery from the stress. Plants growing under the three treatment conditions were maintained for additional two weeks: Fe0 (always grown without Fe; $\mathrm{n}>36$ ); Fe10 (control plants, always grown with Fe; $\mathrm{n}>42$ ), and FeR (chlorotic plants treated by adding Fe to nutrient solution; $n>20$ ). The containers used in the experiment were placed in a randomized design, each one with six plants.

\subsection{Leaf chlorophyll assessment}

During the experimental period, leaf Chl concentrations were estimated non-destructively using the Chlorophyll Metre SPAD-502 device (Minolta Camera Co., Osaka, Japan), at least thrice a week. SPAD readings began 12 days after the development of the first/ second new leaves. For comparison purposes one mature-basal leaf and one fully-expanded new leaf (apical leaf) were measured. To account for leaf heterogeneity, SPAD values were taken in all three leaflets of each leaf. SPAD readings were converted into total Chl concentration ( $\mu \mathrm{mol} \mathrm{m} \mathrm{m}^{-2}$ ) using the calibration curve for 'Diamante' strawberry:

$$
\begin{aligned}
\mathrm{Chl} & =0.38 \times \mathrm{SPAD}^{2}+6.63 \times \mathrm{SPAD}+71.55\left(\mathrm{r}^{2}=0.97 ; \mathrm{n}\right. \\
& =38 ; \mathrm{P}<0.001) .
\end{aligned}
$$

This calibration curve was established by extracting pigments from leaves with different degrees of chlorosis from the same area where SPAD readings were carried out. Pigment extraction was done with pure acetone and then Chl was measured spectrophotometrically in the presence of $\mathrm{Na}$ ascorbate (Abadía and Abadía, 1993).

\subsection{Biomass}

Strawberry plants (at least 5 per treatment) were harvested at four different stages: (i) (day 1) - before the beginning of the experiment plants without leaves were divided into roots and crown; (ii) (day 15) two weeks after the imposition of Fe treatments; plants were divided into roots, crown, young leaves and flowers; (iii) (day 35) - when Fe0 plants developed Fe deficiency symptoms; plants from each treatment ( $\mathrm{Fe} 0$ and $\mathrm{Fe} 10$ ) were separated into roots, crowns, mature leaves, young leaves and flowers; (iv) (day 47) at the end of the recovery period plants from each treatment ( $\mathrm{Fe} 0, \mathrm{Fe} 10$ and FeR) were separated into roots, crown, mature leaves, young leaves, flowers and runners. Samples were washed with a non-ionic detergent $(0.1 \%)$ to remove surface contamination, then with tap water, and finally rinsed three times with deionised water. Fresh weight (FW) was determined for each collected sample and dry weight (DW) estimated after drying at $60{ }^{\circ} \mathrm{C}$ until constant weight.

\subsection{Mineral composition}

Dried samples were ground to powder, ashed at $450{ }^{\circ} \mathrm{C}$ and digested with $\mathrm{HCl}(1 \mathrm{M})$ according to standard laboratory procedures (A.O.A.C., 1990). Total N and P concentrations were determined by the Kjeldahl and molybdo-vanadate methods, respectively. Potassium, $\mathrm{Ca}, \mathrm{Mg}, \mathrm{Cu}, \mathrm{Mn}, \mathrm{Zn}$ and Fe concentrations 
were measured by atomic absorption spectrophotometry. Macronutrients concentrations are expressed as $\mathrm{g} \mathrm{kg}^{-1}$ DW and micronutrients as $\mathrm{mg} \mathrm{kg}^{-1} \mathrm{DW}$. Fe content was calculated by multiplying the DW of each plant organ by their measure Fe concentration.

\subsection{Determination of Fe-chelate reducing capacity of roots}

The activity of the root ferric-chelate reductase (FCR; EC 1.16.1.17) was determined spectrophotometrically by following the formation of a red Fe(II)-(BPDS) 3 complex (Bienfait et al., 1983). Root tips of approximately $2 \mathrm{~cm}(3.4 \mathrm{mg} \pm 0.3$ ) were excised with a razor blade, immersed in $900 \mu \mathrm{l}$ of micronutrient-free half strength Hoagland's nutrient solution, containing $300 \mu \mathrm{M}$ BPDS (bathophenathroline dissulfonic acid), $500 \mu \mathrm{M}$ Fe(III)-EDTA and $5 \mathrm{mM}$ MES at $\mathrm{pH} 6.0$, and incubated for $1 \mathrm{~h}$ in the dark. Iron reduction rates were determined by measuring the absorbance at $535 \mathrm{~nm}$ against blanks controls (without root tips) using an extinction coefficient of $22.14 \mathrm{mM} \mathrm{cm}^{-1}$. Blank controls were used to correct for any unspecific Fe reduction during the same period of time. Root tips were then blotted on paper towel and their fresh weight determined. FCR activity of root tips was performed under laboratory conditions at 15,35 and 47 days after the beginning of the experiment and using at least three random replicates (root tips) from at least five plants of each treatment.

\subsection{Organic acid extraction and quantification}

For each Fe treatment root tips (with approximately $2 \mathrm{~cm}$ of length; $100 \mathrm{mg} \pm 10 \mathrm{mg}$ ) and two leaf disks of $1.5 \mathrm{~cm}$ in diameter (approximately $72 \mathrm{mg} \pm 2$ for mature and $59 \mathrm{mg} \pm 3$ for young leaves) were taken 15, 35 and 47 days after the beginning of the experiment using a calibrated cork borer. SPAD values were registered from each disk and then all samples were weighted and immediately frozen at $-80^{\circ} \mathrm{C}$. The extraction of organic acids was carried out as described by (López-Millán et al., 2009). Briefly, plant material was ground into powder with a mortar and pestle using liquid $\mathrm{N}_{2}$. The powder was suspended in $8 \mathrm{mM} \mathrm{H}_{2} \mathrm{SO}_{4}$ and then boiled for $30 \mathrm{~min}$. The samples were then centrifuged at $2320 \times \mathrm{g} \mathrm{rpm}$ for $10 \mathrm{~min}$ and the supernatant filtered through a $0.45 \mu \mathrm{m}$ PTFE filter, the volume taken adjusted to $2 \mathrm{ml}$ and stored at $-80^{\circ} \mathrm{C}$ before analysis.

Citric acid and succinic acid (Fluka Analytical, Epalinges, Switzerland) and malic acid (Merck, Hohenbrunn, Germany) were standard quality and used as received. Isotope labelled compounds, citric acid-2,2,4,4-d4, succinic acid-2,2,3,3-d4 and DL-malic acid2,3,3-d3 were obtained from Sigma Aldrich Inc. (St. Louis, MO, USA). Water was Milli-Q quality (Millipore, Bedford, MA, USA). The quantification of organic acids was performed by LC-MS using a stable-isotope dilution (SDI) methodology. The LC-MS system was an Agilent Technologies 1200 Series LC coupled to a Bruker Daltonics HCT ultra (ion trap analyser) and the ionization was made by electrospray in the negative polarity. The chromatographic separation was done by a SeQuant (Merck) ZIC-pHILIC $(150 \times 2.1 \mathrm{~mm}$, $5 \mu \mathrm{m}$, polymeric beads) column. Each sample was analysed for succinic, malic and citric acids, using the correspondent internal standards for quantification. The concentration of the internal standards, citric acid-2,2,4,4-d4, succinic acid-2,2,3,3-d4 and DLmalic acid-2,3,3-d3 in all standard solutions samples were $100 \mu \mathrm{M}$, $50 \mu \mathrm{M}$ and $50 \mu \mathrm{M}$, respectively. The detection limits ranged from 4 to $16 \mathrm{pmol}$ for succinic and malic and 100 pmol for citric acid. The quantification was carried out using peak areas and the final values were expressed in $\mu \mathrm{mol} \mathrm{g}^{-1}$ fresh weight (FW).

\subsection{Statistical analysis}

Analysis of variance (ANOVA; F test) for all treatments and conditions and the averages compared using the Duncan Multiple Range Test (DMRT) at $P<0.05$ (IBM SPSS ${ }^{\circledR}$ software version 20).

\section{Results}

\subsection{Chlorophyll concentration}

In the present study the chlorophyll content of young leaves of plants growing under Fe0 conditions, as measured by SPAD, after 12 days was already significantly lower (890 $\mu \mathrm{mol} \mathrm{Chl} \mathrm{m}{ }^{-2}$; Fig. 1A) when compared with contents of control plants

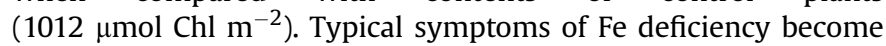
clear after 21 days, showing an interveinal chlorosis which evolved to a generalised and severe chlorosis (Fig. 2). After 35 days young leaves of $\mathrm{Fe} 0$ plants were severely chlorotic, showing chlorophyll contents of $200 \pm 10 \mu \mathrm{mol} \mathrm{m}{ }^{-2}$, about 5 times lower than control plants.

Iron resupply started after 34 days. Seven days after the resupply (day $\mathbf{4 2}$ of experiment) the chlorophyll contents of youngest leaves (FeR plants) already had increased by 4 -fold and after 12 days chlorophyll levels were the same as control plants (Fe10) and the leaves become uniformly green, indicating a complete recouver of the iron deficiency (Fig. 2). The chlorophyll contents of mature leaves decreased but never reached the low levels observed for young leaves (Fig. 1 B). In mature leaves of FeR plants the chlorophyll concentration increased but remained smaller than in Fe10 plants.
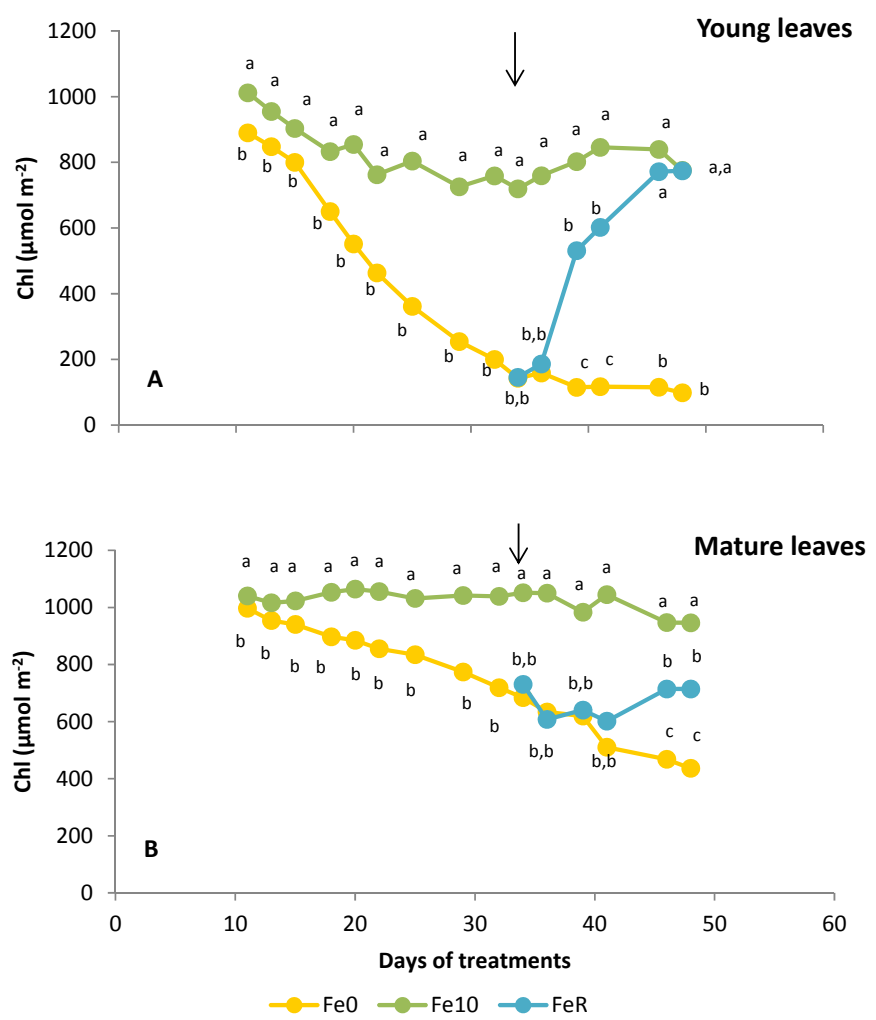

Fig. 1. Total leaf chlorophyll concentration $\left(\mathrm{Chl}, \mu \mathrm{mol} \mathrm{m}{ }^{-2}\right.$ ) of young $\left.\mathbf{A}\right)$, and mature $\mathbf{B}$ ) leaves for the different treatments during the experimental period. $\mathrm{Fe} 0$ - without $\mathrm{Fe}$ in nutrient solution; Fe10 - with Fe in the nutrient solution; FeR - plants without Fe followed by $10 \mu \mathrm{m}$ Fe10 in the nutrient solution. The black arrow indicates the beginning of Fe resupply. For each date, means with different letters are statistically different at $P<0.05$ (Duncan's multiple range test; $\mathrm{n} \geq 20$ ). 


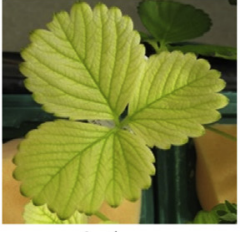

0 days

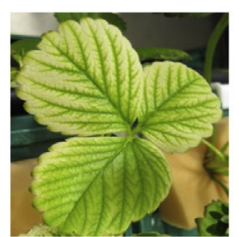

1 days



2 days

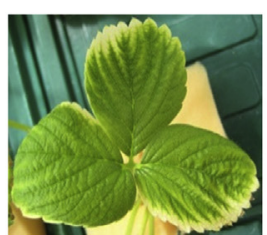

6 days



12 days

Resupply time, from $35^{\text {th }}$ to $47^{\text {th }}$ day of experiment

Fig. 2. Regreening pattern of young chlorotic strawberry leaves over 12 days after the resupply of Fe (FeR).

\subsection{Biomass}

No significant differences on the biomass partition were observed between $\mathrm{Fe} 0$ and $\mathrm{Fe} 10$ plants after 15 days (Fig. 3). However, after $\mathbf{3 5}$ days, the biomass of the crown was significantly higher in Fe10 plants, which is associated to the production of several runners. At the end of the experiment Fe10 plants accumulated more biomass in all organs comparatively to chlorotic plants (Fe0) and recovered plants (FeR). The latter had more biomass in crowns and in young leaves than $\mathrm{Fe} 0$ plants but did not reach the values of Fe10 plants. In other organs no significant differences were observed between FeR and Fe0 plants.

At the end of the experiment the root system of Fe0 plants was smaller, showing less biomass, but more ramified than that of Fe10 plants (Fig. 3). Root to shoot ratios were significantly higher in $\mathrm{Fe}$ deficient plants, showing $0.35 \pm 0.02$ as compared to $0.22 \pm 0.01$ for control plants $(\mathrm{P}<0.05)$ and $0.26 \pm 0.01$ for FeR plants (data not shown). Concerning the number of leaves it was observed that $\mathrm{Fe} 0$ plants had fewer leaves than Fe10 plants, whereas FeR plants had an in-between value (3.0-4.4 and 3.6 respectively, $P<0.05$ in all cases; data not shown).

\subsection{Nutrient partition}

The mineral composition was measured after 15, 35 and 47 days) in different plants organs (Table 1, for macronutrients and
Table 2, for micronutrients) and growing conditions. After 15 and 35 days slight differences in nutrient partition were found between treatments. The level $\mathrm{Cu}$ in roots was an exception, being 2.5 and 4.2 times higher in $\mathrm{Fe} 0$ plants as compared to Fe10, increasing to 5.7 times by day 47 . Interestingly, by 35th day, no differences in Fe concentration in any organ were observed between $\mathrm{Fe} 0$ plants and control plants grown with Fe.

At the end of the experiment the nitrogen concentration in the roots of recovered plants (FeR) and $\mathrm{K}, \mathrm{P}$ and $\mathrm{Ca}$ in crowns, show values similar to the obtained for Fe10 plants. In mature leaves the concentrations of N, P K and Ca in FeR plants were also similar to control plants.

As for micronutrients (Table 2), $\mathrm{Cu}$ concentrations in the crown and in runners of FeR were similar to Fe10 plants. Moreover, in young leaves $\mathrm{Zn}$ values were similar in both treatments and so was Mn concentration in flowers. Noteworthy were the concentrations of $\mathrm{Cu}, \mathrm{Zn}$ and $\mathrm{Mn}$ measured in the roots of recovered plants, which were higher than those of Fe10 plants. With reference to Fe uptake these plants also had significantly higher values of Fe in flowers, leaves and crowns as compared to Fe10 plants.

Iron accumulated preferentially in the roots and crowns (Fig. 4). The total Fe content in the four organs at day 15 (2173 $\mu$ g plant $^{-1}$ ) was not significantly different from that of plants grown without $\mathrm{Fe}$ (Fe0, $1781 \mu \mathrm{g}$ plant $^{-1}$ ). By day 35, Fe10 plants had significant higher values of $\mathrm{Fe}$ in roots and



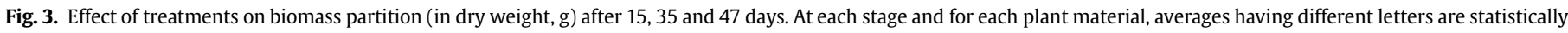
different at $P<0.05$ (Duncan's multiple range test). Statistics are only presented when significant differences are present. 
Table 1

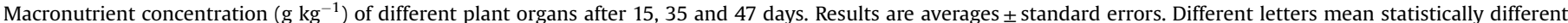



\begin{tabular}{|c|c|c|c|c|c|c|c|c|c|c|c|}
\hline & & \multicolumn{10}{|l|}{$\mathrm{g} \mathrm{kg}^{-1}$} \\
\hline & & \multicolumn{2}{|l|}{$\mathrm{N}$} & \multicolumn{2}{|l|}{$\mathrm{P}$} & \multicolumn{2}{|l|}{$\mathrm{K}$} & \multicolumn{2}{|l|}{$\mathrm{Mg}$} & \multicolumn{2}{|l|}{$\mathrm{Ca}$} \\
\hline \multicolumn{12}{|l|}{ Day 15} \\
\hline \multirow[t]{2}{*}{ Flowers } & $\mathrm{Fe} 0$ & nd & & $9.5 \pm 0.7$ & ns & $33 \pm 1.3$ & ns & $4.0 \pm 0.3$ & ns & $11.1 \pm 0.6$ & ns \\
\hline & Fe10 & nd & & $8.0 \pm 0.4$ & & $29 \pm 3.1$ & & $3.6 \pm 0.2$ & & $10.1 \pm 0.9$ & \\
\hline \multirow[t]{2}{*}{ Young leaves } & $\mathrm{Fe} 0$ & $50 \pm 1.6$ & ns & $9.5 \pm 0.2$ & $* *$ & $41 \pm 1.3$ & ns & $3.7 \pm 0.1$ & ns & $10.8 \pm 0.7$ & ns \\
\hline & Fe10 & $47 \pm 1.8$ & & $7.7 \pm 0.4$ & & $39 \pm 1.7$ & & $3.7 \pm 0.1$ & & $9.3 \pm 0.5$ & \\
\hline \multirow[t]{2}{*}{ Crown } & $\mathrm{Fe} 0$ & $18 \pm 0.2$ & ns & $2.7 \pm 0.1$ & ns & $14 \pm 0.8$ & ns & $2.5 \pm 0.1$ & ns & $10.2 \pm 0.4$ & $* *$ \\
\hline & Fe10 & $17 \pm 1.0$ & & $2.8 \pm 0.1$ & & $11 \pm 0.6$ & & $2.4 \pm 0.2$ & & $7.6 \pm 0.5$ & \\
\hline \multirow[t]{2}{*}{ Roots } & $\mathrm{Fe} 0$ & $22 \pm 0.3$ & ns & $3.7 \pm 0.1$ & ns & $12 \pm 0.2$ & $*$ & $3.6 \pm 0.2$ & ns & $7.9 \pm 0.5$ & ns \\
\hline & Fe10 & $21 \pm 0.4$ & & $3.6 \pm 0.2$ & & $11 \pm 0.1$ & & $3.8 \pm 0.4$ & & $6.0 \pm 0.4$ & \\
\hline \multicolumn{12}{|l|}{ Day 35} \\
\hline \multirow[t]{2}{*}{ Flowers } & $\mathrm{Fe} 0$ & $28 \pm 1.3$ & ns & $7.4 \pm 0.2$ & ns & $41 \pm 1.4$ & $*$ & $4.4 \pm 0.4$ & ns & $9.5 \pm 0.4$ & $* *$ \\
\hline & Fe10 & $29 \pm 0.5$ & & $6.3 \pm 0.5$ & & $36 \pm 0.6$ & & $3.6 \pm 0.2$ & & $7.4 \pm 0.5$ & \\
\hline \multirow[t]{2}{*}{ Young leaves } & $\mathrm{Fe} 0$ & $36 \pm 0.8$ & $*$ & $7.2 \pm 0.2$ & $*$ & $38 \pm 0.4$ & ns & $4.3 \pm 0.0$ & ns & $9.5 \pm 0.4$ & $*$ \\
\hline & Fe10 & $33 \pm 0.1$ & & $6.6 \pm 0.1$ & & $41 \pm 1.4$ & & $4.2 \pm 0.0$ & & $12.3 \pm 0.8$ & \\
\hline \multirow[t]{2}{*}{ Mature leaves } & $\mathrm{Fe} 0$ & $35 \pm 0.1$ & $* *$ & $8.4 \pm 0.3$ & ns & $53 \pm 1.5$ & $* * *$ & $5.4 \pm 0.1$ & $* * *$ & $17.5 \pm 0.4$ & *** \\
\hline & Fe10 & $36 \pm 0.1$ & & $7.5 \pm 0.2$ & & $44 \pm 0.6$ & & $4.3 \pm 0.1$ & & $13.9 \pm 0.5$ & \\
\hline \multirow[t]{2}{*}{ Crown } & $\mathrm{Fe} 0$ & $16 \pm 0.3$ & $*$ & $3.0 \pm 0.1$ & ns & $15 \pm 0.5$ & ns & $2.8 \pm 0.0$ & $*$ & $9.8 \pm 0.0$ & *** \\
\hline & Fe10 & $17 \pm 0.3$ & & $2.8 \pm 0.1$ & & $13 \pm 0.5$ & & $3.1 \pm 0.1$ & & $10.8 \pm 0.1$ & \\
\hline \multirow[t]{2}{*}{ Roots } & $\mathrm{Fe} 0$ & $20 \pm 0.3$ & $* *$ & $4.6 \pm 0.1$ & ns & $11 \pm 0.5$ & ns & $4.4 \pm 0.3$ & ns & $8.4 \pm 0.3$ & ns \\
\hline & Fe10 & $22 \pm 0.2$ & & $4.9 \pm 0.4$ & & $12 \pm 1.1$ & & $3.7 \pm 0.2$ & & $9.3 \pm 0.3$ & \\
\hline \multicolumn{12}{|l|}{ Day 47} \\
\hline \multirow[t]{3}{*}{ Flowers } & $\mathrm{Fe} 0$ & $25 \pm 1$ & ns & $8 \pm 0$ & $\mathrm{~b}$ & $37 \pm 2$ & ns & $4 \pm 0$ & $\mathrm{a}$ & $10 \pm 0$ & ns \\
\hline & Fe10 & $28 \pm 1$ & & $9 \pm 0$ & $\mathrm{a}$ & $41 \pm 1$ & & $3 \pm 0$ & $\mathrm{~b}$ & $10 \pm 0$ & \\
\hline & FeR & $27 \pm 1$ & & $7 \pm 0$ & $\mathrm{~b}$ & $42 \pm 2$ & & $4 \pm 0$ & $\mathrm{a}$ & $10 \pm 1$ & \\
\hline \multirow[t]{3}{*}{ Young leaves } & $\mathrm{Fe} 0$ & $32 \pm 0.7$ & $\mathrm{ab}$ & $10.9 \pm 0.6$ & $\mathrm{a}$ & $36 \pm 0.7$ & ns & $4.0 \pm 0.1$ & $\mathrm{a}$ & $10.8 \pm 0.1$ & $\mathrm{a}$ \\
\hline & Fe10 & $31 \pm 0.5$ & $\mathrm{~b}$ & $6.6 \pm 0.2$ & $\mathrm{~b}$ & $32 \pm 0.6$ & & $2.7 \pm 0.0$ & c & $8.2 \pm 0.1$ & c \\
\hline & FeR & $34 \pm 0.4$ & $\mathrm{a}$ & $7.0 \pm 0.1$ & $\mathrm{~b}$ & $34 \pm 1.4$ & & $3.7 \pm 0.1$ & $\mathrm{~b}$ & $9.7 \pm 0.1$ & $\mathrm{~b}$ \\
\hline \multirow[t]{3}{*}{ Mature leaves } & $\mathrm{Fe} 0$ & $28 \pm 0.6$ & $\mathrm{~b}$ & $8.4 \pm 0.4$ & $\mathrm{a}$ & $50 \pm 1.7$ & $\mathrm{a}$ & $4.9 \pm 0.2$ & $\mathrm{a}$ & $15.9 \pm 0.9$ & $\mathrm{a}$ \\
\hline & Fe10 & $31 \pm 0.4$ & $\mathrm{a}$ & $7.3 \pm 0.1$ & $\mathrm{~b}$ & $39 \pm 0.2$ & $\mathrm{~b}$ & $3.7 \pm 0.1$ & c & $13.6 \pm 0.3$ & $\mathrm{~b}$ \\
\hline & FeR & $33 \pm 0.5$ & $\mathrm{a}$ & $7.1 \pm 0.1$ & $\mathrm{~b}$ & $39 \pm 0.6$ & $\mathrm{~b}$ & $4.4 \pm 0.1$ & $\mathrm{~b}$ & $12.2 \pm 0.6$ & $\mathrm{~b}$ \\
\hline \multirow[t]{3}{*}{ Runners } & $\mathrm{Fe} 0$ & $27^{\mathrm{A}}$ & nd & $6.3 \pm 0.5$ & ns & $29 \pm 1.9$ & $\mathrm{~b}$ & $3.2 \pm 0.3$ & $\mathrm{a}$ & $7.5 \pm 1.8$ & $\mathrm{a}$ \\
\hline & $\mathrm{Fe} 10$ & $24 \pm 0.1$ & & $6.9 \pm 0.2$ & & $34 \pm 0.3$ & $\mathrm{a}$ & $2.2 \pm 0.1$ & $\mathrm{~b}$ & $4.8 \pm 0.1$ & $\mathrm{ab}$ \\
\hline & FeR & $26^{\mathrm{A}}$ & & $8.7 \pm 2.9$ & & $33 \pm 1.5$ & $\mathrm{ab}$ & $2.3 \pm 0.3$ & $\mathrm{~b}$ & $4.3 \pm 0.2$ & $\mathrm{~b}$ \\
\hline \multirow[t]{3}{*}{ Crown } & $\mathrm{Fe} 0$ & $17 \pm 0.3$ & $\mathrm{a}$ & $6.0 \pm 0.3$ & $\mathrm{a}$ & $12 \pm 0.8$ & $\mathrm{~b}$ & $3.3 \pm 0.1$ & ns & $11.5 \pm 0.4$ & $\mathrm{a}$ \\
\hline & Fe10 & $14 \pm 0.2$ & c & $3.7 \pm 0.0$ & b & $17 \pm 0.6$ & $\mathrm{a}$ & $2.8 \pm 0.0$ & & $9.4 \pm 0.1$ & $\mathrm{~b}$ \\
\hline & FeR & $15 \pm 0.4$ & $b$ & $4.4 \pm 0.1$ & $\mathrm{~b}$ & $16 \pm 0.4$ & $\mathrm{a}$ & $3.1 \pm 0.3$ & & $10.0 \pm 0.6$ & $\mathrm{~b}$ \\
\hline Roots & $\mathrm{Fe} 0$ & $20 \pm 0.7$ & $\mathrm{~b}$ & $6.8 \pm 1.1$ & ns & $11 \pm 1.1$ & ns & $4.2 \pm 0.6$ & ns & $9.9 \pm 0.1$ & $\mathrm{a}$ \\
\hline & Fe10 & $24 \pm 0.4$ & $\mathrm{a}$ & $7.1 \pm 0.1$ & & $11 \pm 0.5$ & & $4.2 \pm 0.2$ & & $9.3 \pm 0.1$ & $\mathrm{a}$ \\
\hline & FeR & $23 \pm 0.9$ & $\mathrm{a}$ & $6.9 \pm 0.2$ & & $11 \pm 0.9$ & & $4.4 \pm 0.3$ & & $7.9 \pm 0.3$ & $\mathrm{~b}$ \\
\hline
\end{tabular}

flowers. At the end of the experiment, Fe10 plants showed higher Fe content in all organs, except for the crown where no significant differences were observed for all treatments. FeR plants reached the Fe contents of Fe10 plants in several organs, namely roots, mature leaves and young leaves. Surprisingly, the levels of Fe observed in the crown and in flowers of FeR plants were significantly higher than those of control plants that grew always with Fe. The Fe content in crowns of FeR plants was almost double compared to Fe10 plants, and it was $40 \%$ higher in flowers.

\subsection{Root ferric-chelate reductase activity}

Up to Fe resupply (35 days) the $\mathrm{pH}$ of the nutrient solution was the same in both Fe treatments $(6.0 \pm 0.5)$. However, the total FCR activity measured in root tips was higher in $\mathrm{Fe} 10$ plants than $\mathrm{Fe} 0$ plants (Fig. 5). The activity decreased along the experiment, showing, after 15 days, 15 and $21 \mathrm{nmol} \mathrm{Fe}(\mathrm{II}) \mathrm{min}^{-1} \mathrm{~g}^{-1} \mathrm{FW}$ in $\mathrm{Fe} 0$ and Fe10 plants respectively, decreasing then to 6 and 9 nmol Fe(II) $\mathrm{min}^{-1} \mathrm{~g}^{-1} \mathrm{FW}$ after 47 days. Modifications in root morphology, such as development of secondary roots, were observed after 20 days. Similar trend was observed by the end of the experiment but values were not significant different for the three treatments. However FeR plants decreased the emission of lateral roots from 37th day to the 41 st.

\subsection{Organic acids}

Differences in the concentration of organic acids were mainly observed between mature leaves and roots (Fig. 6) of $\mathrm{FeO}$ and $\mathrm{Fe} 10$ plants. At the end of the experiment both, succinic and citric acids increased in the roots of FeR plants as compared to Fe0 and Fe10 plants, while the concentration of all acids in mature leaves was similar to that of Fe10 plants.

In short, shoots of Fe0 plants tended to accumulate organic acids while the opposite was observed in their roots.

\section{Discussion}

Strawberry plants are known to be very susceptible to Fe deficiency (Kafkas et al., 2007; Torun et al., 2013). Typical Fe chlorosis symptoms have been observed mainly in young leaves. Previous studies using the "Diamante" cultivar also indicated chlorosis of young leaves but also show that Fe stress does not induce permanent damages in the photosynthetic apparatus (Osório et al., 2014) and the observed total leaf re-greening of FeR plants are in agreement with these studies. The rapid response to the resupply of iron has been assigned to a quick access of Fe via xylem to young leaves (Pestana et al., 2012b). This metabolic efficiency also leads to significant biomass recouver of FeR plants at the end of the experiment, although smaller than the observed for plants grown always 
Table 2

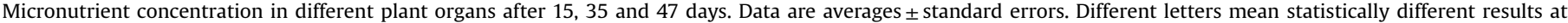
$\mathrm{P}<0.05$ (Duncan's multiple range test). Significant differences are indicated: *, $\mathrm{P}<0.05$; ns, not significant.

\begin{tabular}{|c|c|c|c|c|c|c|c|c|c|c|}
\hline & & \multicolumn{9}{|l|}{$\mathrm{mg} \mathrm{kg}^{-1}$} \\
\hline & & \multicolumn{2}{|l|}{$\mathrm{Cu}$} & \multicolumn{2}{|l|}{$\mathrm{Zn}$} & \multicolumn{2}{|l|}{ Mn } & \multicolumn{3}{|l|}{$\mathrm{Fe}$} \\
\hline \multicolumn{11}{|l|}{ Day 15} \\
\hline \multirow[t]{2}{*}{ Flowers } & $\mathrm{Fe} 0$ & $32 \pm 5$ & $*$ & $29 \pm 3$ & $* * *$ & $406 \pm 18$ & ns & $238 \pm 94$ & ns & \\
\hline & Fe10 & $56 \pm 1$ & & $88 \pm 8$ & & $446 \pm 48$ & & $250 \pm 3$ & & \\
\hline \multirow[t]{2}{*}{ Young leaves } & $\mathrm{Fe} 0$ & $13 \pm 1$ & ns & $37 \pm 3$ & ns & $633 \pm 67$ & ns & $130 \pm 25$ & ns & \\
\hline & Fe10 & $14 \pm 0$ & & $34 \pm 0$ & & $563 \pm 66$ & & $157 \pm 5$ & & \\
\hline \multirow[t]{2}{*}{ Crown } & $\mathrm{Fe} 0$ & $13 \pm 1$ & ns & $60 \pm 5$ & ns & $368 \pm 26$ & * & $907 \pm 61$ & ns & \\
\hline & Fe10 & $11 \pm 1$ & & $62 \pm 2$ & & $279 \pm 25$ & & $1087 \pm 108$ & & \\
\hline \multirow[t]{2}{*}{ Roots } & $\mathrm{Fe} 0$ & $40 \pm 5$ & $* * *$ & $79 \pm 1$ & $* *$ & $677 \pm 36$ & ns & $1159 \pm 118$ & ns & \\
\hline & Fe10 & $16 \pm 1$ & & $96 \pm 3$ & & $518 \pm 133$ & & $1414 \pm 70$ & & \\
\hline \multicolumn{11}{|l|}{ Day 35} \\
\hline \multirow[t]{2}{*}{ Flowers } & $\mathrm{Fe} 0$ & $16 \pm 2$ & ns & $42 \pm 3$ & $*$ & $250 \pm 14$ & ns & $41 \pm 10$ & & ns \\
\hline & Fe10 & $14 \pm 3$ & & $50 \pm 2$ & & $369 \pm 75$ & & $60 \pm 5$ & & \\
\hline \multirow{2}{*}{ Young leaves } & $\mathrm{Fe} 0$ & $17 \pm 1$ & ns & $43 \pm 4$ & ns & $306 \pm 10$ & ns & $48 \pm 5$ & & ns \\
\hline & Fe10 & $16 \pm 1$ & & $39 \pm 1$ & & $363 \pm 29$ & & $59 \pm 2$ & & \\
\hline \multirow[t]{2}{*}{ Mature leaves } & $\mathrm{Fe} 0$ & $16 \pm 1$ & $* *$ & $30 \pm 1$ & $* *$ & $617 \pm 24$ & ns & $93 \pm 4$ & & ns \\
\hline & Fe10 & $13 \pm 0$ & & $35 \pm 1$ & & $674 \pm 29$ & & $122 \pm 16$ & & \\
\hline \multirow[t]{2}{*}{ Crown } & $\mathrm{Fe} 0$ & $15 \pm 0$ & $*$ & $70 \pm 2$ & $* * *$ & $233 \pm 14$ & $* *$ & $730 \pm 56$ & & ns \\
\hline & Fe10 & $10 \pm 1$ & & $84 \pm 4$ & & $263 \pm 6$ & & $689 \pm 17$ & & \\
\hline \multirow{2}{*}{ Roots } & $\mathrm{Fe} 0$ & $131 \pm 5$ & $* * *$ & $181 \pm 8$ & $* * *$ & $1135 \pm 76$ & $*$ & $1311 \pm 108$ & & ns \\
\hline & Fe10 & $31 \pm 2$ & & $125 \pm 6$ & & $876 \pm 16$ & & $1645 \pm 189$ & & \\
\hline \multicolumn{11}{|l|}{ Day 47} \\
\hline \multirow[t]{3}{*}{ Flowers } & $\mathrm{Fe} 0$ & $12 \pm 1$ & ns & $34 \pm 2$ & $\mathrm{ab}$ & $280 \pm 14$ & $\mathrm{~b}$ & $36 \pm 6$ & $\mathrm{~b}$ & \\
\hline & Fe10 & $9 \pm 1$ & & $40 \pm 2$ & $\mathrm{a}$ & $297 \pm 10$ & $\mathrm{ab}$ & $10 \pm 2$ & $\mathrm{~b}$ & \\
\hline & FeR & $9 \pm 1$ & & $28 \pm 1$ & $\mathrm{~b}$ & $333 \pm 18$ & $\mathrm{a}$ & $74 \pm 7$ & $\mathrm{a}$ & \\
\hline \multirow[t]{3}{*}{ Young leaves } & $\mathrm{Fe} 0$ & $19 \pm 2$ & ns & $39 \pm 2$ & $\mathrm{a}$ & $382 \pm 24$ & $\mathrm{a}$ & $58 \pm 6$ & $\mathrm{~b}$ & \\
\hline & Fe10 & $12 \pm 1$ & & $23 \pm 1$ & $\mathrm{~b}$ & $195 \pm 10$ & $\mathrm{~b}$ & $65 \pm 3$ & $\mathrm{~b}$ & \\
\hline & FeR & $9 \pm 4$ & & $25 \pm 1$ & $\mathrm{~b}$ & $334 \pm 13$ & $\mathrm{a}$ & $120 \pm 12$ & $\mathrm{a}$ & \\
\hline \multirow[t]{3}{*}{ Mature leaves } & $\mathrm{Fe} 0$ & $3 \pm 1$ & $\mathrm{~b}$ & $36 \pm 2$ & $\mathrm{a}$ & $504 \pm 16$ & $\mathrm{a}$ & $49 \pm 5$ & $\mathrm{~b}$ & \\
\hline & Fe10 & $5 \pm 0$ & $\mathrm{~b}$ & $31 \pm 1$ & $\mathrm{~b}$ & $386 \pm 3$ & $\mathrm{~b}$ & $46 \pm 2$ & $\mathrm{~b}$ & \\
\hline & FeR & $11 \pm 2$ & $\mathrm{a}$ & $24 \pm 1$ & c & $442 \pm 29$ & $\mathrm{ab}$ & $82 \pm 6$ & $\mathrm{a}$ & \\
\hline \multirow[t]{3}{*}{ Runners } & $\mathrm{Fe} 0$ & $19 \pm 4$ & $\mathrm{a}$ & $45 \pm 5$ & ns & $179 \pm 17$ & $\mathrm{a}$ & $26 \pm 4$ & $\mathrm{~b}$ & \\
\hline & Fe10 & $6 \pm 2$ & $\mathrm{~b}$ & $35 \pm 4$ & & $115 \pm 7$ & $\mathrm{~b}$ & $55 \pm 3$ & $a b$ & \\
\hline & FeR & $9 \pm 1$ & b & $33 \pm 6$ & & $153 \pm 28$ & $\mathrm{ab}$ & $82 \pm 14$ & $\mathrm{a}$ & \\
\hline \multirow[t]{3}{*}{ Crown } & $\mathrm{Fe} 0$ & $24 \pm 5$ & $\mathrm{a}$ & $94 \pm 5$ & ns & $213 \pm 11$ & $\mathrm{a}$ & $950 \pm 15$ & $\mathrm{a}$ & \\
\hline & Fe10 & $16 \pm 1$ & $\mathrm{ab}$ & $92 \pm 2$ & & $147 \pm 6$ & $\mathrm{c}$ & $513 \pm 4$ & $\mathrm{~b}$ & \\
\hline & FeR & $11 \pm 2$ & $\mathrm{~b}$ & $91 \pm 2$ & & $202 \pm 15$ & $\mathrm{~b}$ & $1131 \pm 131$ & $\mathrm{a}$ & \\
\hline \multirow[t]{3}{*}{ Roots } & $\mathrm{Fe} 0$ & $153 \pm 5$ & $\mathrm{a}$ & $346 \pm 9$ & $\mathrm{a}$ & $1519 \pm 63$ & $\mathrm{a}$ & $1187 \pm 49$ & ns & \\
\hline & Fe10 & $27 \pm 2$ & c & $154 \pm 13$ & c & $614 \pm 22$ & $\mathrm{c}$ & $1201 \pm 107$ & & \\
\hline & FeR & $42 \pm 3$ & $\mathrm{~b}$ & $233 \pm 6$ & $\mathrm{~b}$ & $1101 \pm 30$ & $\mathrm{~b}$ & $1427 \pm 107$ & & \\
\hline
\end{tabular}
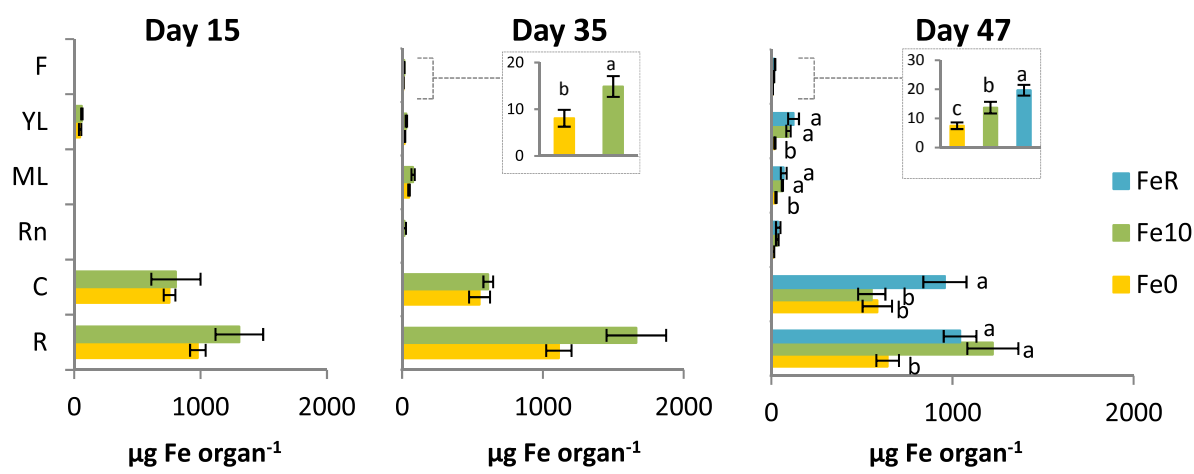

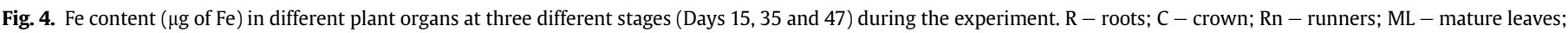
$\mathrm{YL}$ - young leaves; F - flowers. Data are averages \pm standard errors. Different letters mean statistically different results at $P<0.05$ (Duncan's multiple range test).

in the presence of $\mathrm{Fe}(\mathrm{Fe} 10)$.

Iron chlorosis studies using the strawberry cultivar "Selva" (Pestana et al., 2012b) reported higher FCR activity under iron stress as well as root acidification, which have been described for a large number of species (Pestana et al., 2012b, 2013; Torun et al., 2013). In our experiment however, chlorotic plants exhibited lower FCR activity compared to control plants. This response may be related to the rapid growth characteristic of this cultivar, a strategy which is often observed in species registering low FCR activity in Fe depleted conditions (Jiménez et al., 2008; Pestana et al., 2012a) or caused by a low tolerance to Fe deficiency. Similar results were also obtained by Venturas et al. (2014) that reported lower FCR activity in chlorotic elm species compared to plants that developed in Fe sufficient conditions. Similar behaviour has reported in grapevine and in tomato (Siminis and Stavrakakis, 2008; Zouari et al., 2001). 


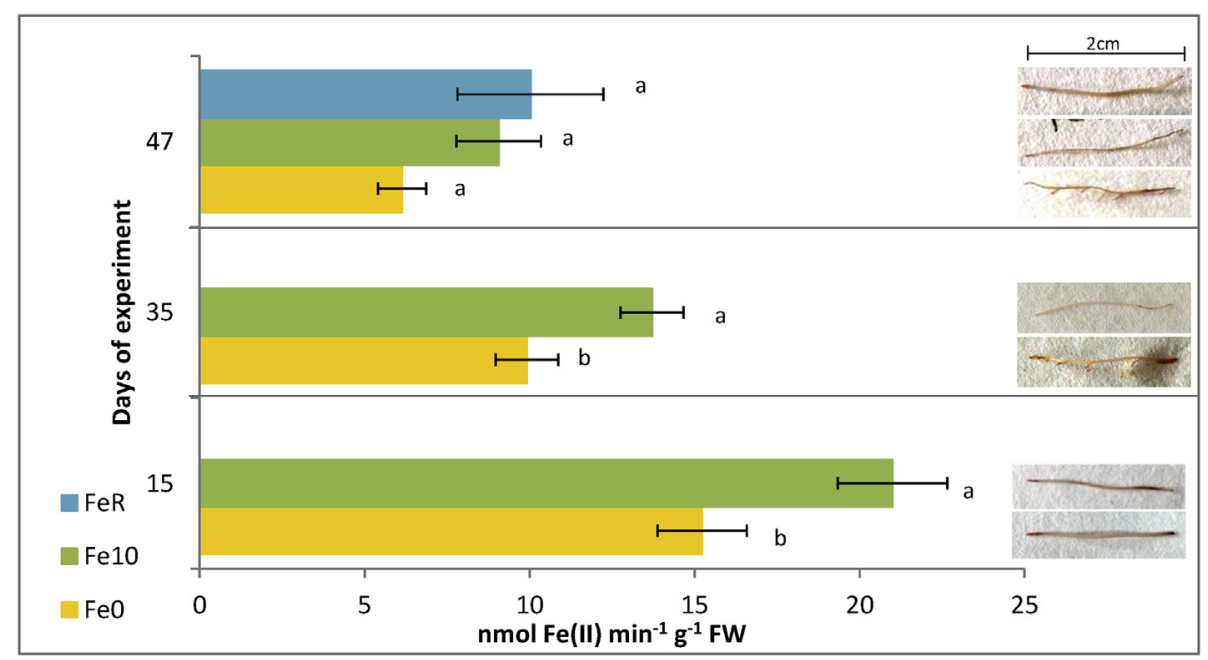

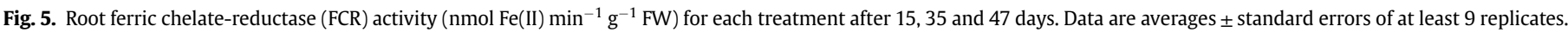
For each collecting time, columns showing different letters indicate significant differences at $P<0.05$ (Duncan's multiple range test).

\section{Organic acids $\left(\mu \mathrm{mol} \mathrm{g}^{-1} \mathrm{FW}\right)$}

Succinic

\section{Young Leaves}
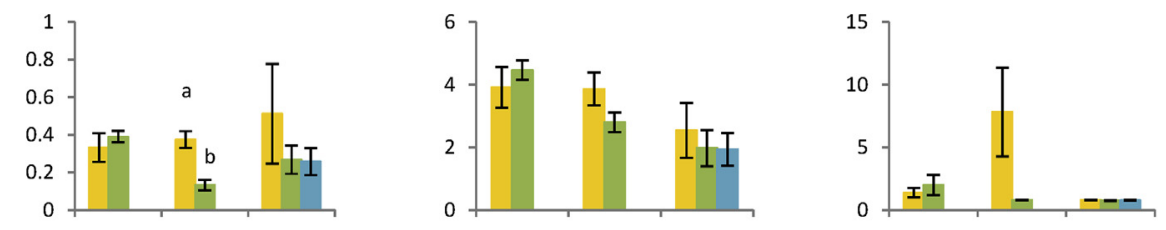

\section{Mature Leaves}
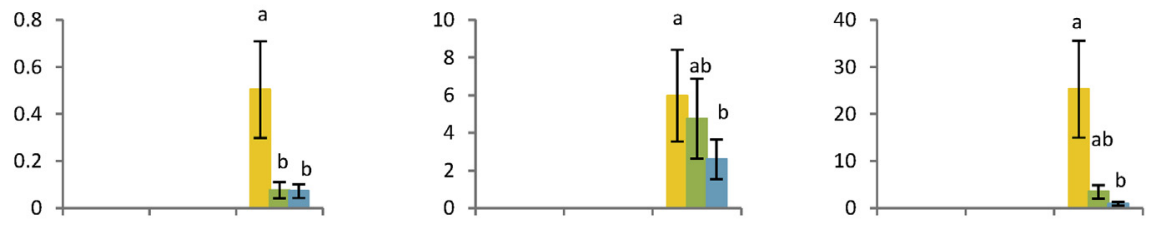

\section{Roots}
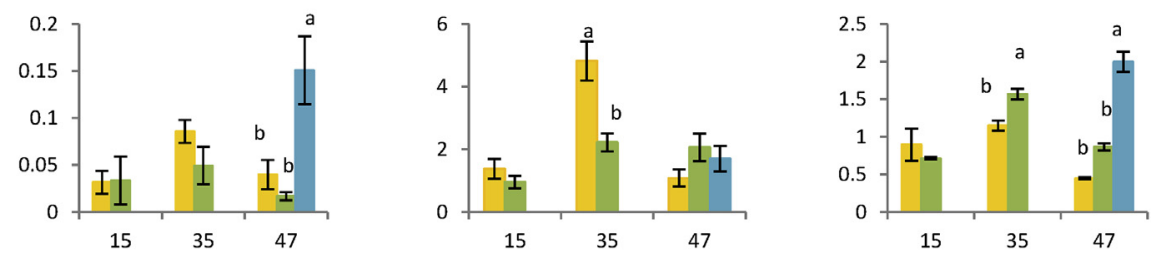

\section{$\mathrm{Fe} 0 \mathrm{Fe} 10 \square \mathrm{FeR}$}

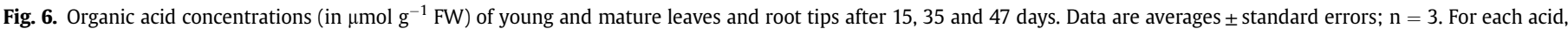
organ, and collecting time, columns showing different letters mean the results are statistically different, at $P<0.05$ (Duncan's multiple range test). 
To rationalize the results we hypothesize that the root FCR activity of the cultivar "Diamante" seems to be regulated by Fe itself. In chlorotic plants showed clear morphological root adaptations and lateral root ramifications were produced. This morphological change may amplify the reduction points in roots allowing a higher Fe uptake (Pestana et al., 2011). After Fe resupply, there was a boost of Fe reduction, as observed from the FCR values at day 47, thus explaining the high Fe contents in all organs of recovered plants. While Fe-sufficient plants accumulated Fe mainly in mature leaves, recovered plants altered the sink pattern, mobilizing Fe to flowers and crown. Depending on environmental conditions, the crown produces a modified terminal stem or inflorescence (Costes et al., 2014; Heide et al., 2013; Menzel and Smith, 2014), and under stress conditions it is possible that the plants had changed the standard nutritional source-sink pathways.

The increment of $\mathrm{Fe}$ in flowers of recovered plants is a particularly interesting result. In strawberry, Valentinuzzi et al. (2014) found higher concentration of several health beneficial compounds, such as benzoic acid and flavonols, in fruits of plants grown under Fe and $\mathrm{P}$ deficiency. This result pointed to a selective management of nutrients as a tool to improve specific fruit quality traits. In our experiment fruits were not analysed, but it is expectable that the clear increase of total plant Fe will be extended to the edible parts of the plants.

Under Fe deficiency conditions (Fe0), plants accumulated $\mathrm{N}$ and $\mathrm{P}$ in the crown, and $\mathrm{K}$ in mature leaves. $\mathrm{Cu}$ and $\mathrm{Zn}$ also accumulated in several organs and in most cases, the concentrations were higher than in control plants. It is possible that $\mathrm{Cu}$ may be taken up instead of Fe when Fe is absent (Pestana et al., 2013) since there is a physiological link between the two metals (Cohu and Pilon, 2007; Fox, 2003; Palmer and Guerinot, 2009). However, a possible "concentration effect" cannot be discarded since Fe0 plants showed less biomass. In recovered plants, the resupply of Fe and total regreening lead to specific outcome besides Fe uptake. FCR system is able to reduce other micronutrients such as $\mathrm{Mn}^{3+}$ and $\mathrm{Cu}^{2+}$ and Fe transporters are also able to carry other micronutrients that can move easily in the xylem sap (Grusak et al., 1999; Pestana et al., 2013). The increase of $\mathrm{N}$ in mature leaves may be related to Chl biosynthesis, and ultimately to protein build-up, a request to meet new growth demand of recovered plants.

Organic acid concentrations of mature and young leaves increased as a result to Fe deficiency ( $\mathrm{Fe} 0$ ) which seems to occur in a number of species to target additional energy requirements, proton extrusion, Fe solubilisation by primary reduction and subsequently uptake throughout the plant (Larbi et al., 2010; LópezMillán et al., 2009). Correia et al. (2014) pointed the importance of malic and citric acid in Fe homoeostasis. The decrease in malic and citric acid concentrations in root tips of Fe deficient plants may be due to root exudation, an effort to chelate Fe in the rhizosphere for uptake (López-Millán et al., 2009).

However, after Fe resupply a boost of succinic acid and citric acid occurred mainly in roots and not in leaves, which may be interpreted as a direct effect of Fe addition to the nutrient solution. The hypothesis is that the excess of acids which were present in mature leaves of Fe deficient plants, moved downward as a response to $\mathrm{Fe}$ signalling upon the recovering process. In this view, some upregulated mechanism had occurred.

\section{Conclusions}

In conclusion, under the experimental conditions presented in this work, an Fe pulse supplied to the nutrient solution to chlorotic strawberry plants led to the recovery from this deficiency in 12 days. Fe partition was directed to crown and flowers which might be due to a slow deactivation mechanism of FCR activity associated with accumulation of succinic and citric acids at a root level and consequent greater uptake of Fe.

\section{Contributions}

F. Gama, P.J. Correia and M. Pestana wrote the manuscript. F. Gama and T. Saavedra executed the experiments. J.P. Silva performed the LC-MS organic acid determination. A. de Varennes was responsible for mineral composition analysis. All authors contributed to the discussion of the results.

\section{Acknowledgements}

This study was funded by the National Project (PTDC/AGR-PRO/ 3861/2012) from the Fundação para a Ciência e Tecnologia (FCT). F.Gama is thankful to FCT for the grant SFRH/BD/89521/2012.

\section{References}

A.O.A.C. 1990. Association of Official Agricultural Chemists. Official Methods of Analysis, twelf ${ }^{\text {th }}$ ed. (Washington, D.C).

Abadía, J., Abadía, A., 1993. Iron and pigments. In: Barton, L.L., Hemming, B.C. (Eds.), Iron Chelation in Plants and Soil Microorganisms. Academic Press Inc., San Diego, CA, USA, pp. 327-343.

Abadía, J., López-Millán, A.-F., Rombolà, A., Abadía, A., 2002. Organic acids and Fe deficiency: a review. Plant Soil 241, 75-86. http://dx.doi.org/10.1023/A: 1016093317898

Bienfait, H.F., Bino, R.J., Van der Blick, A.M., Duivenvoorden, J.F., Fontaine, J.M., 1983. Characterization of ferric reducing activity in roots of Fe-deficient Phaseolus vulgaris. Physiol. Plant. 59, 196-202. http://dx.doi.org/10.1111/j.13993054.1983, tb00757x.

Cohu, C.M., Pilon, M., 2007. Regulation of superoxide dismutase expression by copper availability. Physiol. Plant. 129, 747-755. http://dx.doi.org/10.1111/ j.1399-3054.2007.00879.x.

Correia, P.J., Gama, F., Saavedra, T., Miguel, M.G., Da Silva, J.P., Abadía, A., de Varennes, A., Pestana, M., 2014. Changes in the concentration of organic acids in roots and leaves of carob-tree under Fe deficiency. Funct. Plant Biol. 41, 496-504. http://dx.doi.org/10.1071/FP13204.

Costes, E., Crespel, L., Denoyes, B., Morel, P., Demene, M.-N., Lauri, P.-E., Wenden, B., 2014. Bud structure, position and fate generate various branching patterns along shoots of closely related Rosaceae species: a review. Front. Plant Sci. 5 http://dx.doi.org/10.3389/fpls.2014.00666.

Domenico Rombolà, A., Toselli, M., Carpintero, J., Ammari, T., Quartieri, M., Torrent, J., Marangoni, B., 2003. Prevention of iron-deficiency induced chlorosis in kiwifruit (Actinidia deliciosa) through soil application of synthetic Vivianite in a calcareous soil. J. Plant Nutr. 26, 2031-2041. http://dx.doi.org/10.1081/PLN120024262.

Fox, P.L., 2003. The copper-iron chronicles: the story of an intimate relationship. Biometals 16, 9-40.

Gayomba, S.R., Zhai, Z., Jung, H.-i., Vatamaniuk, O.K., 2015. Local and systemic signaling of iron status and its interactions with homeostasis of other essential elements. Front. Plant Sci. 6, 716. http://dx.doi.org/10.3389/fpls.2015.00716.

Giampieri, F., Alvarez-Suarez, J.M., Battino, M., 2014. Strawberry and human health: effects beyond antioxidant activity. J. Agric. Food Chem. 62, 3867-3876. http:// dx.doi.org/10.1021/jf405455n.

Giampieri, F., Forbes-Hernandez, T.Y., Gasparrini, M., Alvarez-Suarez, J.M., Afrin, S., Bompadre, S., Quiles, J.L., Mezzetti, B., Battino, M., 2015. Strawberry as a health promoter: an evidence based review. Food \& Funct. 6, 1386-1398. http:/ dx.doi.org/10.1039/c5fo00147a.

Grusak, M.A., Pearson, J., Marentes, E., 1999. The physiology of micronutrient homeostasis in field crops. Field Crops Res. 60, 41-56. http://dx.doi.org/10.1016/ S0378-4290(98)00132-4

Heide, O., Stavang, J., Sønsteby, A., 2013. Physiology and genetics of flowering in cultivated and wild strawberries-a review. J. Hort. Sci. Biotechnol. 88, 1-18. http://dx.doi.org/10.1080/14620316.2013.11512930.

Hindt, M.N., Guerinot, M.L., 2012. Getting a sense for signals: regulation of the plant iron deficiency response. Biochimica Biophysica Acta BBA Mol. Cell Res. 1823, 1521-1530. http://dx.doi.org/10.1016/j.bbamcr.2012.03.010.

Jeong, J., Guerinot, M.L., 2009. Homing in on iron homeostasis in plants. Trends Plant Sci. 14, 280-285. http://dx.doi.org/10.1016/j.tplants.2009.02.006.

Jiménez, S., Pinochet, J., Abadía, A., Moreno, M.Á., Gogorcena, Y., 2008. Tolerance response to iron chlorosis of Prunus selections as rootstocks. HortScience 43 304-309.

Kafkas, E., Silberbush, M., Paydas, S., 2007. Physiological characterization of strawberry cultivars with differential susceptibility to iron deficiency. World J. Agric. Sci. 3, 196-203.

Larbi, A., Abadía, A., Abadía, J., Morales, F., 2006. Down co-regulation of light absorption, photochemistry, and carboxylation in Fe-deficient plants growing in different environments. Photosynth. Res. 89, 113-126. http://dx.doi.org 
10.1007/s11120-006-9089-1.

Larbi, A., Morales, F., Abadía, A., Abadía, J., 2010. Changes in iron and organic acid concentrations in xylem sap and apoplastic fluid of iron-deficient Beta vulgaris plants in response to iron resupply. J. plant Physiol. 167, 255-260. http:// dx.doi.org/10.1016/j.jplph.2009.09.007.

López-Millán, A.F., Morales, F.n., Abadía, A., Abadía, J., 2000. Effects of iron deficiency on the composition of the leaf apoplastic fluid and xylem sap in sugar beet. implications for iron and carbon transport. Plant Physiol. 124, 873-884. http://dx.doi.org/10.1104/pp.124.2.873.

López-Millán, A.F., Morales, F., Gogorcena, Y., Abadía, A., Abadía, J., 2001a. Iron resupply-mediated deactivation of Fe-deficiency stress responses in roots of sugar beet. Funct. Plant Biol. 28, 171-180. http://dx.doi.org/10.1071/PP00105.

López-Millán, A.F., Morales, F., Gogorcena, Y., Abadía, A., Abadía, J., 2009. Metabolic responses in iron deficient tomato plants. J. plant Physiol. 166, 375-384. http:// dx.doi.org/10.1016/j.jplph.2008.06.011.

López-Millán, A.F., Morales, F., Abadía, A., Abadía, J., 2001b. Changes induced by Fe deficiency and Fe resupply in the organic acid metabolism of sugar beet (Beta vulgaris) leaves. Physiol. Plant. 112, 31-38. http://dx.doi.org/10.1034/j.13993054.2001.1120105.x.

Manganaris, G.A., Goulas, V., Vicente, A.R., Terry, L.A., 2014. Berry antioxidants: small fruits providing large benefits. J. Sci. Food Agric. 94, 825-833. http:// dx.doi.org/10.1002/jsfa.6432.

Marschner, H., Römheld, V., Kissel, M., 1986. Different strategies in higher plants in mobilization and uptake of iron. J. Plant Nutr. 9, 693-713. http://dx.doi.org/ 10.1080/01904168609363475.

Menzel, C.M., Smith, L., 2014. The growth and productivity of 'Festival'strawberry plants growing in a subtropical environment. N. Z. J. Crop Hortic. Sci. 42, 60-75. http://dx.doi.org/10.1080/01140671.2013.850439.

Muneer, S., Jeong, B.R., Kim, T.-H., Lee, J.H., Soundararajan, P., 2014. Transcriptional and physiological changes in relation to $\mathrm{Fe}$ uptake under conditions of $\mathrm{Fe}$ deficiency and Cd-toxicity in roots of Vigna radiata L. J. plant Res. 127, 731-742. http://dx.doi.org/10.1007/s10265-014-0660-0.

Ortas, I., Kaya, Z., Ercan, S., 2015. Effect of pyrite application on wheat-maize growth and nutrient uptake under diverse soil conditions. J. Plant Nutr. 38, 295-309. http://dx.doi.org/10.1080/01904167.2014.957392.

Osório, J., Osório, M.L., Correia, P.J., de Varennes, A., Pestana, M., 2014. Chlorophyll fluorescence imaging as a tool to understand the impact of iron deficiency and resupply on photosynthetic performance of strawberry plants. Sci. Hortic. 165, 148-155. http://dx.doi.org/10.1016/j.scienta.2013.10.042.

Palmer, C.M., Guerinot, M.L., 2009. Facing the challenges of $\mathrm{Cu}, \mathrm{Fe}$ and $\mathrm{Zn}$ homeostasis in plants. Nat. Chem. Biol. 5, 333-340. http://dx.doi.org/10.1038/ nchembio.

Pestana, M., de Varennes, A., Faria, E.A., 2003. Diagnosis and correction of iron chlorosis in fruit trees: a review. Food, Agric. Environ. 1, 46-51.

Pestana, M., de Varennes, A., Abadía, J., Faria, E.A., 2005. Differential tolerance to iron deficiency of citrus rootstocks grown in nutrient solution. Sci. Hortic. 104, 25-36. http://dx.doi.org/10.1016/j.scienta.2004.07.007.

Pestana, M., Gama, F., Saavedra, T., de Varennes, A., Correia, P., 2012a. The root ferric-chelate reductase of Ceratonia siliqua (L.) and Poncirus trifoliata (L.) Raf responds differently to a low level of iron. Sci. Hortic. 135, 65-67. http:// dx.doi.org/10.1016/j.scienta.2011.12.018.

Pestana, M., Correia, P.J., Saavedra, T., Gama, F., Abadía, A., de Varennes, A., 2012b. Development and recovery of iron deficiency by iron resupply to roots or leaves of strawberry plants. Plant Physiol. Biochem. 53, 1-5. http://dx.doi.org/10.1016/ j.plaphy.2012.01.001.

Pestana, M., Correia, P.J., Saavedra, T., Gama, F., Dandlen, S., Nolasco, G., Varennes, A.d, 2013. Root ferric chelate reductase is regulated by iron and copper in strawberry plants. J. Plant Nutr. 36, 2035-2047. http://dx.doi.org/ 10.1080/01904167.2013.816731.

Pestana, M., Domingos, I., Gama, F., Dandlen, S., Miguel, M.G., Castro Pinto, J., de Varennes, A., Correia, P.J., 2011. Strawberry recovers from iron chlorosis after foliar application of a grass-clipping extract. J. Plant Nutr. Soil Sci. 174, 473-479. http://dx.doi.org/10.1002/jpln.201000215.

Rellán-Álvarez, R., Giner-Martínez-Sierra, J., Orduna, J., Orera, I., RodríguezCastrillón, J.Á., García-Alonso, J.I., Abadía, J., Álvarez-Fernández, A., 2010. Identification of a tri-iron (III), tri-citrate complex in the xylem sap of iron-deficient tomato resupplied with iron: new insights into plant iron long-distance transport. Plant Cell Physiol. 51, 91-102. http://dx.doi.org/10.1093/pcp/pcp170.

Rubio, V., Bustos, R., Irigoyen, M.L., Cardona-López, X., Rojas-Triana, M., Paz-Ares, J., 2009. Plant hormones and nutrient signaling. Plant Mol. Biol. 69, 361-373. http://dx.doi.org/10.1007/s11103-008-9380-y.

Siminis, C.I., Stavrakakis, M.N., 2008. Iron induces root and leaf ferric chelate reduction activity in grapevine rootstock 140 Ruggeri. HortScience 43 , 685-690.

Sperotto, R.A., Vasconcelos, M.W., Grusak, M.A., Fett, J.P., 2012. Effects of different Fe supplies on mineral partitioning and remobilization during the reproductive development of rice (Oryza sativa L.). Rice 5, 27. http://dx.doi.org/10.1186/19398433-5-27.

Torun, A.A., Serce, S., Kacar, Y.A., Erdem, N., Erdem, H., Bicen, B., Tolay, I., 2013. Determination of factors affecting sensitivity of two strawberry species to iron deficiency. Int. J. Food, Agric. Environ. 11, 785-789.

Valentinuzzi, F., Mason, M., Scampicchio, M., Andreotti, C., Cesco, S., Mimmo, T. 2014. Enhancement of the bioactive compound content in strawberry fruits grown under iron and phosphorus deficiency. J. Sci. Food Agric. http:// dx.doi.org/10.1002/jsfa.6924.

Venturas, M., Fernández, V., Nadal, P., Guzmán, P., Lucena, J.J., Gil, L., 2014. Root iron uptake efficiency of Ulmus laevis and U. minor and their distribution in soils of the Iberian Peninsula. Front. Plant Sci. 5 http://dx.doi.org/10.3389/ fpls.2014.00104.

Zocchi, G., De Nisi, P., Dell'Orto, M., Espen, L., Gallina, P.M., 2007. Iron deficiency differently affects metabolic responses in soybean roots. J. Exp. Bot. 58, 993-1000. http://dx.doi.org/10.1093/jxb/erl259.

Zouari, M., Abadía, A., Abadía, J., 2001. Iron is required for the induction of root ferric chelate reductase activity in iron-deficient tomato. J. Plant Nutr. 24, 383-396. http://dx.doi.org/10.1081/PLN-100001396. 